\title{
Professional Development Practices, Promotions and Organizational Commitment: A Propoundment of Professional Integration Interaction Practices (PIIP) Model
}

\author{
S. M. Muyiggwa and F. P. Kiyingi
}

\section{ABSTRACT}

Public universities in Uganda have been challenged by levels of organisational commitment of their academic staff. This study alluded to influence of professional development practices at Makerere and Kyambogo universities on organisational commitment of the academic staff. The study used a descriptive cross-sectional survey design with both qualitative and quantitative approaches, with a study sample of $\mathbf{3 2 0}$ academic staffs from both Makerere and Kyambogo Universities, selected using simple random and purposive sampling techniques. The study data were anlysed using Pearson Product Moment Correlation Coefficient and regression analysis, whereas qualitative data were thematically analyzed. Further analysis was done using Structural Equation Modeling (SEM). The Human Capital theory and the Equity theory guided the study. SEM showed that horizontal promotion as an avenue of staff promotions had an insignificant positive direct influence on organizational commitment $(\beta=$ $0.002, p=0.972>0.05$ ). While informal learning as a professional development practice had an insignificant direct effect on organizational commitment $(\beta=0.033, p=0.537>0.05)$. These findings, coupled with the limitations in the Human Capital and Equity theories, led to the Professional Integration Interaction Practices (PIIP) model proposed by the study. The study concluded that, University Councils in conjunction with management in Makerere and Kyambogo Universities, and the Ministry of Education and Sports through National Council of Higher Education, should adopt the PIIP Model with a view to raise professional standards and hence organizational commitment of academic staff.

Keywords: Academic Staff in Uganda, Organisational Commitment, PIIP Model, Professional Integration Interaction Practices

\section{INTRODUCTION}

Professional development of university staff is a continuous concern to many stakeholders (Richards \& Farrell, 2005). Accordingly professional development keeps universities focused to their mandate as centers of research and innovation (UNESCO, 1998; Plater, 1995). In the same vein high organizational commitment of employees leads firms to success as employees accept the firm's mission, goals and objectives (Unzicker et al., 2000). Thus high organizational commitment of academic staff, who are the backbone of universities, should be ensured for the survival of these institutions (Fako et al., 2018). However, despite the critical influence of organizational commitment of staff on organizational effectiveness, Mugizi et al. (2015) indicate that there is low organizational commitment of academic staff in Ugandan Universities.

\author{
Published Online: January 31, 2022 \\ ISSN: $2736-4534$ \\ DOI: $10.24018 /$ ejedu.2022.3.1.243 \\ S. M. Muyiggwa* \\ Lecturer, School of Graduate Studies, \\ Business Department, Bugema \\ University, Uganda. \\ (e-mail: muyiggwa.saul7 ${ }^{\circledR}$ gmail.com) \\ F. P. Kiyingi \\ Senior Lecturer, Department of \\ Counseling Psychology, School of \\ Education, Social Sciences, Law, \\ Nkumba University, Uganda. \\ (e-mail: kfrankpio ${ }^{@}$ yahoo.com )
}

*Corresponding Author 
before end of contract in 2015 were $68.5 \%$ (Uganda Bureau of Statistics (UBOS), 2018). This is indicative of low continuance commitment in the education sector. Similarly, statistics show that from 2014 to $2019,25 \%$ of the academic staff who left Makerere University prematurely had reasons associated with inadequate organizational commitment "unpublished" (Directorate of Human Resources, Makerere University 2019). Consequently, resignations, which are an indicator of low affective and continuance commitment, constitute $77.5 \%$ of the $25 \%$ of the academic staff who leave the university before end of contract. Kyambogo University has got similar trends, as in 2014 it lost 43 top academic staff (Oyat \& Aleni, 2015; Inspectorate of Government, 2015) and between 2015 and 2019 the number of senior academic staff dropped by $6 \%$, which explicitly indicated inadequate continuance commitment but implicitly, raised concerns on affective and normative commitment (Inspectorate of Government, 2015; Directorate of Human Resources, Kyambogo University, 2019). Nonetheless, professional development practice often contributes to higher employee organizational commitment (Mathias \& Jackson, 20008). Similarly, organizational commitment of academic staffs is one of the important factors for ensuring the effectiveness of the university (Hanaysha, 2016; Thabo et al., 2018).

Hence it is critical to curtail this trend of inadequate organizational commitment as it might negatively affect smooth operations and effectiveness in the two universities. An empirical study therefore, was needed to establish the influence of professional development practices on organizational commitment of academic staff in Kyambogo and Makerere Universities with a view of solving the problem.

\section{A. Professional Development Practices and Organizational Commitment}

The study considered professional development practices to involve informal learning opportunities (ILOs) such as; mentoring, induction, coaching, action research and online learning, and formal training opportunities (FTOs) like; inservice training, study leaves, conferences and seminars. These variables were investigated in the sense in which they influence organizational commitment as manifested in terms of affective, normative and continuance commitment of academic staff in Makerere and Kyambogo Universities.

The ILOs or on-the-job training is recognized as an important component of continuous professional development which explains a growing body of literature that considers contributions of informal learning elements on continuous professional development. In this regard Rawashdeh and Tamimi (2019) studied the impact of employee perception of training on organizational commitment using a quantitative research design, and posted that there exists a strong relationship between perceived availability of training and organizational commitment. Rawashdeh and Tamimi (2019) further reported that perceived benefits of training are negatively related to organizational commitment. They also revealed that there is a strong negative association between organizational and turnover intentions. Rawashdeh and Tamimi (2019) focused their study on perception of employees about training. However, the present study opined that besides perceptions, availability and types of training ought to be considered, as these may also have an influence on organization commitment. The hospital context which Rawashdeh and Tamimi (2019) investigated also provided a gap for the present study, as it presents different scenarios of employee commitment from that of the academic staffs in a university since the learning, training and promotions for both contexts have different demands and expectations.

Other scholars like Mansoor (2017) studied the relationship between training satisfaction and readiness to transfer learning through the mediating role of normative commitment, and the findings first revealed a positive significant relationship between, training satisfaction and normative commitment. Mansoor (2017) further posted that through training forms of coaching, mentoring and monitoring - there was a high possibility to have normative commitment improving among employees. However, Mansoor (2017) only investigated certain components of informal learning predictors of normative commitment, as opposed to the present study which included online learning and action research as well. These two components were added as predictors of organizational commitment in agreement with Hathon and Dillon (2018) who emphasized the components' role in education reform, but also with the present research keeping in mind that Makerere and Kyambogo Universities are academic institutions where research is a core activity.

On the other hand, Khandaker and Pangil (2017) in their study about assessing the relationship between affective commitment and informal work place learning, and with help of descriptive and partial least structural equation modeling, revealed that affective commitment has significant and positive relationship with informal workplace learning. The approach used by Khandaker and Pangil (2017) in their content scope left out normative and continuance commitment and yet they are critical in a university setting. For instance, Ssali, et al. (2019) inferred low continuance organizational commitment as they reported inadequate retention of key academic staff in Makerere and Kyambogo Universities.

Meanwhile, Timsal et al. (2016) in a qualitative study aimed at establishing the factors associated with on-the-job training and its effectiveness, revealed that when employees have job satisfaction as a consequence of on-the-job training, they are more committed to their jobs. However, to avoid the subjectivity that may be associated with the qualitative approach used single handedly, the current study adopted majorly a quantitative approach only supplemented by qualitative method to a small extent for deeper insights about the study variables.

On the other hand, Selemogwe et al. (2013) investigated the role of mentoring as one of the predictors of organizational commitment among non- academic staff of Ibadan University adopting a cross- sectional survey design, and posted that mentoring significantly influenced organizational commitment. However, the present study argued that Selemogwe et al. (2013) left out the academic staff from their study, yet they are a core segment in any university population without which the university would not be. 
Meanwhile, Lambert et al. (2019) had interest in the effects of workplace variables on organizational commitment of Nigerian correctional staff quality and revealed that quality training had positive significant effects on organizational commitment. Lambert et al. (2019) concluded that commitment to the organization is stronger when employees are treated in a positive manner. However, Lambert et al. (2019) left out staff promotions in their study, yet Adam's Equity Theory to organizational commitment.

Similarly, Yangbo and Chul-Ki (2019) also had a target population different from the academic staff when they considered the participation in vocation training program of construction engineers and the impact of both formal and informal learning of human resources on performance with regression analysis established that participation rates in workplace learning is relatively low especially in informal learning. Moreover, they reported that informal learning has a positive effect on organizational commitment. However, the present study aimed at establishing whether academic staff participation in informal learning influenced organizational commitment the same way it did with the engineers whom Yangbo and Chul-Ki (2019) investigated, anchored the Human Capital Theory tenets proposed by Gary Baker in 1964.

In the same vein other researchers have demonstrated that formal training has an influence on organizational commitment. Among recent investigators of this subject, Hanaysha (2016) examined the effects of training on organizational commitment in Malaysian higher education context collecting data using online survey and analysis by structural equation modeling, findings showed that employee formal training has a significant positive effect on organizational commitment. However, Hanaysha (2016) does not indicate the statistics that lead to the structural equation modeling, as opposed to the present study in which the Pearson correlation coefficients for all the relationships in the study were established, providing the basis for the regressions.

Other studies included, Adere (2019) who studied effects of internal marketing on organizational commitment of employees in Awash bank in Ethiopia with use of mixed methods, descriptive methods and inferential statistics, established that training had a significant and positive influence on organizational commitment of employees. Adere (2019) findings were however limited because they could not be generalized to other banks in Ethiopia in contrast to the study at hand which was designed in such way to allow findings from Makerere and Kyambogo Universities to apply to other public universities in Uganda.

Sitienei et al. (2015) investigated the impact of training and development on employee commitment at the department of children's services in Kenya and with use of Pearson's moment correlation coefficient, posting that training and development had a significant effect on employee commitment in the department of children's services. Sitienei et al. (2015) also reported that frequent training offered to employees was significantly linked to the commitment of employees. In the same vein, Castro-Casal et al. (2019) studied the direct effect of empowerment via affective commitment on the extra-role service, and the moderating effect of service training on the empowerment affective commitment extra-role relationship, revealing that for empowerment to lead to greater affective commitment to the organization and extra-role customer service, it is important for employees to perceive that they have received a moderated high level training in customer service. The finding would call for universities to note that once the academic staff feel that they have received sufficient training, they will handle students with more commitment. Nevertheless, the present study went beyond analyzing results at basic level of Pearson correlation coefficient by going an extra mile to use regression analysis and structural equation modeling.

\section{B. Professional development practices and staff promotions}

As implied in the postulates of Gary's 1964 Human Capital Theory (HCT) and the Equity Theory, professional development practices have been linked to employee promotions. For instance, Nelssen et al. (2017) investigated the employability paradox and probed the relationship between six development activities and voluntary turnover mediated by perceived employability by use of two wave longitudinal data. Findings indicated that only upward job transition positively influenced turnover via perceived external employability. Keeping in mind the view held by Bloch and Bates (1995) that employability is about an employee's capacity to influence their career and the conceptualization of the present study, the implication of Nelssen et al. (2017) findings translates into - upward promotion positively influences acquisition of the required skills because of professional development. Nelssen et al. (2017) further found that several development activities were positively related with perceived internal employability, which in the present study scenario is - development activities positively related to horizontal promotions. Meanwhile, Allen et al. (2004) agreed with Nelssen et al. (2017) as they reported that mentoring, which is one of the development practices, related to career outcomes such as salary level and promotion rate. However, the present study used a crosssectional research design as opposed to Nelssen et al. (2017) longitudinal study since the data could be collected from Makerere and Kyambogo Universities in a short time.

Robboy and McLondon (2017) carried out a similar study, probing structured annual faculty review program as it related to professional development and promotion of the Duke University Medical Centre's Pathology department. This was a retrospective observation study spanning over 18 years and the mentoring process focused on annual review processes. Robboy and McLondon (2017) found that there was a rigorous faculty review process that included: annual career counseling, goal-oriented academic careers, monitored advancement to promotion, higher salaries and national recognition. In addition, these findings indicated a positive relationship between mentoring and both upward and horizontal promotion. However, the current study as opposed to literature review, adopted an empirical study approach, since field data could be collected from participants in Makerere and Kyambogo Universities.

Another study by Sanders and De Grip (2004) investigated whether low-skilled workers' participation and task flexibility contributes to their firm internal and firm external 
mobility analyzing data using multinomial logit. Findings revealed that both training participation and task flexibility only influence firm internal employability. Sanders and De Grip (2004) also reported that the workers' participation in training only plays a much more explicit role in their firm internal career as it increased their opportunities in the firm internal labour market. In light of the present study conceptualization, Sanders and De Grip (2004) findings translate in to, formal training and informal learning have an influence on both horizontal and upward promotions. In addition, Sanders and De Grip (2004) also point to the flexibility of training connoting the different ways in which universities practice professional development and these influence horizontal and vertical promotions. But [33] fall short of explicitly relating participation in training and flexibility of training to promotions as understood from the equity theory and HCT and conceptualized in the same way in this study.

Abedi (2011) investigated influential factors on employees' motivation for participation in the in-service training courses based on modified expectancy theory, targeting a population of formal and temporary employees of National Iranian Oil Products Distribution Company in Isfahan and Kurdistan. Abedi (2011) findings revealed that extrinsic valence (Promotions, better pay, monetary bonus, pay increases) were negatively related with participation in the in-service training. Simply put in the present study context, promotions negatively influence motivation to participate in in-service training. However, the contexts which Abedi (2011) and the current study investigated differed and posed, a gap which the later addressed. That is, the financial and other types of support and benefits in oil industry may not influence employees' participation in inservice training the same way it does in an academic institution.

\section{Promotions and organizational commitment}

Determination of the influence of promotions on the organizational commitment of academic staff is critical for the future of continuous professional development. Among investigators of this interaction, $\mathrm{Ng}$ 'the et al. (2012) reviewed literature with an intent to examine factors that determine retention of academic staff in public universities in Kenya, and findings revealed that promotion opportunities are one of the motivators that can be used to enhance retention, which in the current study translates into continuance organizational. However, whereas promotion of academic staff is dependent on teaching, research and publication as argued by Bampoh-Addo and Abedi-Boajo (2014), a number of obstacles have stood in the way of academic staff publishing their works. Ssentongo (2020) in a study 'Politics of academic promotion in Uganda and the predicament of African publication outlets' reported that, promotion processes in Ugandan universities are driven by complex quality checks that are sometimes characterized by rationalized malice against individual academics in settling personal scores and biases against publications from African

Outlets. Moreover, Ng'the et al. (2012) agreed with Bampoh-Addo and Abedi-Boajo (2014) that inconsistent promotion criteria and tagging promotion to availability of finances are among the issues of concern in public universities. Nevertheless Ng'the et al. (2012) arrived at their findings from review of literature, whereas the prevailing conditions favored a research design that enabled the present study to get findings from analysis of field data collected empirically.

On the other hand, Bulut and Culha (2010) who assessed the effects of organizational training on organizational commitment using survey method, established that the benefits of organizational training specifically promotions were highly responsible for enhancement of commitment of employees in organizations. However, Bulut and Culha (2010) used more of confirmatory factor analysis whereas the present study tested hypotheses using linear regression, which allowed identification of magnitudes of variance contributed by each predictor variable. Meanwhile Nachbagavar and Riedl (2010) assessed effects of concepts of plateaus on performance, work satisfaction and commitment, and findings revealed that concepts of career plateaus were independent of performance and commitment. Hence, in the present study scenario, horizontal promotion is independent of organizational commitment. Though Nachbagavar and Riedl (2010) considered only one aspect of promotion, yet the present studied found it necessary to analyze both components of promotion to ascertain the specific influence of each on organizational commitment and how each was influenced by professional development practices. Similarly, Olurotimi et al. (2015) probed motivational factors and teachers' organizational commitment in public secondary schools in Mbale municipality with use of Pearson correlation co-efficient index and established that promotion has a positive significant relationship on organizational commitment. Nevertheless, Olurotimi et al. (2015) considered promotions under motivation while in the current study it was a moderating variable between professional development practices and organizational commitment. The moderating effects of promotions prompted this study's analysis of the linkage between the study independent and dependent variables, arising from consideration of HCT and Equity Theory.

Based on the afore going review of literature, the study conceptualized a direct influence of professional development practices on organizational commitment, and the indirect influence through the moderating effects of staff promotions. Hence, the key concepts in the study were; Professional development practices, organizational commitment and staff promotions. To gain deeper understanding of the concepts the study employed Structural Equation Modeling as detailed in the following section.

\section{FUNCTIONAL INTER-RELATIONS BETWEEN Professional DEVELOPMENT PRACTICES, PROMOTIONS AND ORGANIZATIONAL COMMITMENT AS EXPRESSED IN THE STRUCTURAL EQUATION MODELING}

Structural Equation Modeling following a path analysis established the Functional Inter-relations between Professional Development Practices, Promotion and Organizational Commitment. 
TABLE I: PATH ANALYSIS INDICATING COEFFICIENT AND STANDARD ERROR OF THE FINAL PATH EQUATION MODEL OF FUNCTIONAL INTERRELATIONS BETWEEN PROFESSIONAL DEVELOPMENT PRACTICES, PROMOTIONS AND ORGANIZATIONAL COMMITMENT

\begin{tabular}{cccccc}
\hline \hline Variables & Coefficient & S.E. & Sig. & \multicolumn{2}{c}{$95 \%$ C.I } \\
& & & & Lower & Upper \\
\hline Direct Effects & & & & & \\
\hline $\begin{array}{c}\text { Organizational } \\
\text { Commitment }\end{array}$ & & & & & \\
\hline Upward Promotion & 0.244 & 0.053 & $\begin{array}{c}0.000 \\
* *\end{array}$ & 0.139 & 0.348 \\
Horizontal Promotion & 0.002 & 0.058 & 0.972 & -0.112 & 0.117 \\
Informal & 0.033 & 0.054 & 0.537 & -0.073 & 0.139 \\
Formal & 0.104 & 052 & 0.046 & 0.002 & 0.206 \\
& & & & & \\
\hline
\end{tabular}

\begin{tabular}{|c|c|c|c|c|c|}
\hline \multicolumn{6}{|c|}{ Indirect Effects } \\
\hline \multicolumn{6}{|c|}{ Upward Promotion } \\
\hline Informal & 0.477 & 0.069 & $\begin{array}{c}0.000 \\
* *\end{array}$ & 0.342 & 0.613 \\
\hline Formal & 0.334 & 0.069 & $\begin{array}{c}0.000 \\
* *\end{array}$ & 0.198 & 0.469 \\
\hline \multicolumn{6}{|c|}{ Horizontal Promotion } \\
\hline Informal & 0.421 & 0.063 & $0.000^{* *}$ & 0.297 & 0.545 \\
\hline Formal & 0.300 & 0.063 & $0.000 * *$ & 0.176 & 0.424 \\
\hline
\end{tabular}

SEM structural equation modeling, SEM Model Endogenous Variables; Upward Promotion, Horizontal Promotion; Exogenous Variables; Professional Dev't Practices, CI; Confidence Interval

Results of the Final Path Equation model of Functional Inter-Relations between Professional Development Practices, Promotions and Organizational Commitment indicated that direct links to organizational commitment involved: upward promotion with a significant positive direct influence $(\beta=$ $0.244, p=0.000<0.05)$ and horizontal promotion with an insignificant positive direct influence $(\beta=0.002, p=0.972>$ $0.05)$. Direct links also included informal learning with an insignificant direct effect $(\beta=0.033, p=0.537>0.05)$ and formal training with a significant positive direct influence $(\beta$ $=0.104, \mathrm{p}=0.046<0.05$ ).

The indirect effects included effects on upward promotion: informal learning with a significant indirect positive effect $(\beta$ $=0.477, \mathrm{p}=0.000<0.05)$ and formal training with $\mathrm{a}$ significant indirect positive effect $(\beta=0.334, p=0.000<$ $0.05)$. The other indirect effects were horizontal promotion on which, informal learning had a significant indirect positive effect $(\beta=0.421, p=0.000<0.05)$ and formal training had a significant indirect positive effect $(\beta=0.300, p=0.000<$ $0.05)$.

The above descriptions are also illustrated in Fig. 1. Showing the Path Analysis Model of the Functional Inter Relations between Professional Development Practices, Promotions and Organizational Commitment.

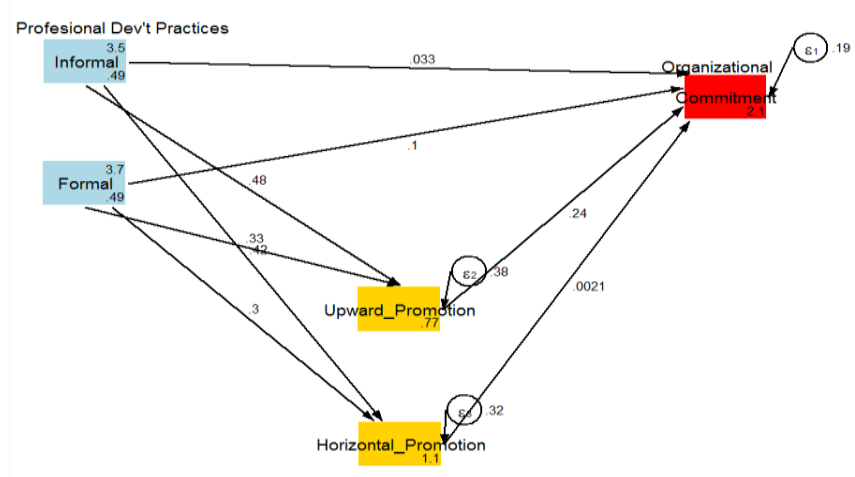

Fig. 1. Path analysis model of the functional inter relations between professional development practices, promotions and organizational commitment.

Fig. 1. Shows a weak path between informal learning opportunities and organization commitment with factor loading of 0.033 . This meant that informal learning opportunities as practiced in Makerere and Kyambogo Universities posted a weak factor loading on organizational commitment. Factors that could be leading to this may include, academic staff not getting fully involved in these activities and not seeing immediate benefits for involvement in the same. It is also indicated in Fig. 1that formal training opportunities have a significant direct positive influence on organizational commitment with a factor loading of 0.100 . This meant that the two Universities needed to add more support to formal training to achieve even higher levels of organizational commitment.

Fig. 1. Also indicated that informal learning opportunities had a strong indirect path through upward promotion with a factor loading of 0.48 . This meant that formal training opportunities predict levels of promotions received by the academic staff. Thus, the two universities need to take advantage of this path since informal learning has insignificant direct effects on organizational commitment. Similarly, there was a strong path between informal learning opportunities and horizontal promotion with a factor loading of 0.33. This meant that informal learning opportunities predict levels of horizontal promotions in academic staff. Hence the Makerere and Kyambogo Universities need to take keen interest in this indirect path in efforts to raise organizational commitment.

It was also shown in Fig. 1. that formal training had a positive significant influence through upward promotion with a factor loading of 0.42 . Similarly, formal training opportunities have a positive significant indirect effect through horizontal promotion with a factor loading of 0.30 . This meant that the two universities needed to sustain support to formal training opportunities as it has both direct and indirect positive and significant effects on organizational commitment. Fig. 1. indicated that upward promotion has a positive significant direct effect on organizational commitment with factor loading of 0.24 . On the other hand, horizontal promotion had a weak path to organizational commitment of factor loading of 0.0021 . This meant that Makerere and Kyambogo Universities needed to make horizontal promotions more meaningful and relevant to the academic staff if it is to contribute to improvement in organizational commitment. 
However when the model was tested for its fitness to describe the inter-relations between the variables, the results indicated a poorly fitting model.

Findings indicated that the goodness of fit statistics with a Root Mean Squared Error of Approximation (RMSEA) = 0.665 . This value, which is greater than 0.1 means a poor fit for the Final Path Equation model. This is also confirmed by the Goodness-of-Fit statistics specifically Comparative Fit Index (CFI) of 0.749 and Tucker-Lewis Index (TLI) of 1.262, which are all, less than the recommended cut off value of 0.95 and above, for a good fit. Similarly, the Standardized Root Mean Squared Residual (SRMSR) $=0.085$ is greater than the recommended cutoff of at least 0.08, a clear indication of a characteristic poor fit of the Final Path Equation model.

To get a best fitting Path Equation Model, all the factors that were statistically insignificant $(p$ Value $>0.05$ ) for endogenous variables and the dependant variables in Final Path Equation model were excluded in the Reduced Path Equation model. Such excluded factors included informal learning $(\beta=0.033, p=0.537)$ and horizontal promotion of academic staff members in Makerere and Kyambogo Universities $(\beta=0.002, p=0.972)$.

The Goodness-of-fit statistics for the Reduced Path Equation model showed a RMSEA $=0.000$. This result showed a good fit for the reduced model compared to the full model since RMSEA is less than 0.10. Furthermore, results showed a SRMSR $=0.006$ less than 0.05 which is equally a good fit with an indication that the reduced path analysis model predicts organizational commitment of academic staff better than the full model.

The CFI $=1.000>0.9$ was also indicative of an acceptable fit of the model in predicting organizational commitment of academic staff in Makerere and Kyambogo Universities. Noting that a better and acceptable fit is demonstrated in the reduced path equation model, Structural Equation Modeling through path analysis was further conducted to get functional interrelations between professional development practices, promotions and organizational commitment. The findings after fitting the reduced path equation model were as presented in Table II and Fig. 2.

Table II showed that staff promotions specifically upward promotion has got a statistically significant positive direct influence on organizational commitment of academic staff in Makerere and Kyambogo Universities $(\beta=0.255, \mathrm{p}=0.000$ $<$ 0.05). Similarly, formal training as a professional development practice has a significant positive direct influence on organizational commitment of academic staff in Makerere and Kyambogo Universities $(\beta=0.119, \mathrm{p}=0.009$ $<0.05)$.

On the other hand, informal learning as a professional development practice has got a statistically significant indirect positive effect on upward promotions received among academic staff members in Makerere and Kyambogo Universities $(\beta=0.477, p=0.000<0.05)$. In the same vein, formal training as a professional development practice has got a statistically significant indirect positive effect on upward promotions received among academic staff members in Makerere and Kyambogo Universities $(\beta=0.334, p=$ $0.000<0.05)$. The above descriptions are also illustrated in Fig. 2.
TABLE II: COEFFICIENT AND STANDARD ERROR OF THE REDUCED PATH EQUATION MODEL OF FUNCTIONAL INTER RELATIONS BETWEEN PROFESSIONAL DEVELOPMENT PRACTICES, PROMOTIONS AND ORGANIZATIONAL COMMITMENT $95 \%$ C.I

\begin{tabular}{|c|c|c|c|c|c|}
\hline \multirow{2}{*}{ Variables } & \multirow{2}{*}{ Coefficient } & \multirow{2}{*}{ S.E. } & \multirow{2}{*}{ Sig. } & \multicolumn{2}{|c|}{$95 \%$ C.I } \\
\hline & & & & Lower & Upper \\
\hline \multicolumn{6}{|l|}{ Direct Effects } \\
\hline \multicolumn{6}{|l|}{$\begin{array}{c}\text { Organizational } \\
\text { Commitment }\end{array}$} \\
\hline Upward Promotion & 0.255 & 0.039 & $\begin{array}{c}0.000 \\
* *\end{array}$ & 0.178 & 0.333 \\
\hline Formal & 0.119 & .045 & $\begin{array}{c}0.009 \\
* *\end{array}$ & 0.030 & 0.209 \\
\hline
\end{tabular}

Indirect Effects

\begin{tabular}{cccccc}
\hline Upward Promotion & \multicolumn{1}{c}{} \\
\hline Informal & 0.477 & 0.069 & $\begin{array}{c}0.000 \\
* *\end{array}$ & 0.342 & 0.613 \\
Formal & 0.334 & 0.069 & $\begin{array}{c}0.000 \\
* *\end{array}$ & 0.198 & 0.469
\end{tabular}

SEM structural equation modeling, SEM Model Endogenous Variables; Upward Promotion, Horizontal Promotion; Exogenous Variables; Professional Dev't Practices, CI; Confidence Interval

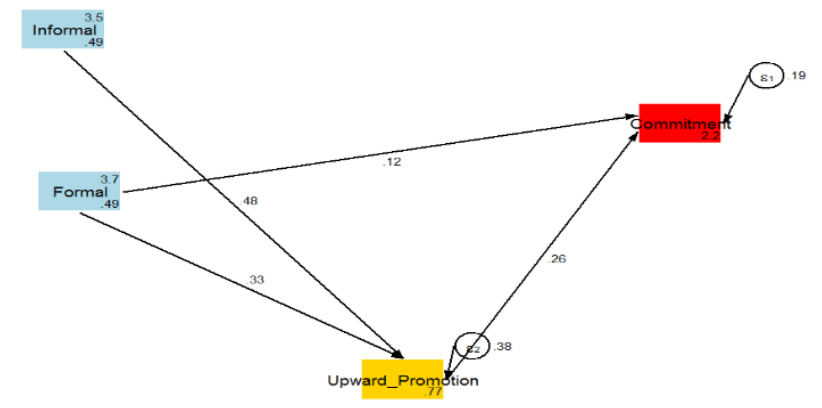

Fig. 2. Reduced path equation model for the functional relationship between professional development practices, promotion and organizational commitment.

\section{A. Assessment of the Different Paths}

The multiplicative model was adopted in an attempt to choose the most significant path in contributing to organizational commitment of academic staff in Makerere and Kyambogo Universities. The direct and indirect total effects were as depicted in Table III.

Findings as shown in Table III. for path 1, indicated that the total effects of informal learning as mediated by upward promotions contributing $12.48 \%$ towards organizational commitment of academic staff. Other path results, that's path 2 for the total effects of formal training mediated by upward promotions as contributing $8.58 \%$ towards organizational commitment of academic staff. Findings in case of path 3, which is the direct effect of formal training as contributing $12.0 \%$ towards organizational commitment of academic staff. Therefore, based on the total effects from the three paths, Path 1 is characterized by the highest contribution towards the organizational commitment of academic staff in Kyambogo and Makerere Universities. 
TABLE III: DIRECT, INDIRECT AND TOT AL EFFECTS ON ORGANIZATIONAL COMMITMENT OF ACADEMIC STAFF

\begin{tabular}{rlcccc}
\hline \hline \multicolumn{1}{c}{ Path } & Effect & & $\begin{array}{c}\text { Effect } \\
\text { Value }\end{array}$ & $\begin{array}{c}\text { Total } \\
\text { Effects }\end{array}$ \\
\hline & $\begin{array}{l}\text { Informal } \\
\text { Learning } \rightarrow\end{array}$ & 0.48 & $\begin{array}{l}\text { Upward } \\
\text { Promotion } \rightarrow \\
\text { Commitment }\end{array}$ & 0.26 & 0.1248 \\
& $\begin{array}{l}\text { Upward } \\
\text { Promotion } \\
\text { Formal }\end{array}$ & & & & \\
& $\begin{array}{l}\text { Training } \\
\text { Upward } \\
\text { Promotion } \\
\text { Formal } \\
\text { Training } \rightarrow \\
\text { Commitment }\end{array}$ & 0.33 & $\begin{array}{l}\text { Upward } \\
\text { Promotion } \rightarrow \\
\text { Commitment }\end{array}$ & 0.26 & 0.0858 \\
\hline \hline
\end{tabular}

\section{B. The Gaps}

The background presented above, created gaps which formed the basis for propounding a new model. For instance, findings of the study showed that horizontal promotion as an avenue of staff promotions had an insignificant positive direct influence on organizational commitment $(\beta=0.002, \mathrm{p}=$ $0.972>0.05)$. While informal learning as a professional development practice had an insignificant direct effect on organizational commitment $(\beta=.033, \mathrm{p}=0.537>0.05)$. Indeed, when informal learning and horizontal promotion were removed from the final model, the resulting model had a good-fit. This meant that the theories which were used to explain the relationships between the variables of the study, had fundamental slips hence the failure to provide basis for some interactions. Therefore, there was need to develop a new model that could take care of all variables of the study.

In fact, the two theories, the human capital theory (HCT) and equity theory (ET), which anchored the current study have been criticized some scholars. Steven (2016) and Tan (2014) raised fundamental questions about the internal logic of the HCT framework focusing the argument on empirical work- dealing with the impact of education and economic growth and the conceptual base of the theory. For this study, the argument tantamount to doubting whether as per the HCT, skills and horizontal promotion received by employees would be accompanied by economic benefits resulting into improved organizational commitment. If there are no corresponding economic benefits, then Steven (2016) and Tan (2014)'s concern explains why informal learning and horizontal promotions posted insignificant results as reported above. This would be true since academic staffs do not see direct financial benefits from skills gained from informal training, and horizontal promotions may not as well come with financial gains. Going by this line of thought, HCT fails to explain some interactions between professional development practices and organizational commitment, hence the need to come up with a new model.

Among other concerns, Olaniyan and Okemakinde (2008) argued that the HCT fails to account for a growing gap between people's increasing learning efforts and knowledge base and the diminishing number of commensurate jobs to apply their increasing knowledge investment, especially in developed nations. In the present study, this argument further explains the insignificant results from informal learning and horizontal promotion in that when the academics receive skills, they are expecting these skills to prepare them for promotions. However, qualitative results indicated that the academic staffs are frustrated with the promotional procedures. Moreover, promotions were reported to have been halted in some instances pending availability of funds. In this case, the human capital investment would not match the available opportunities, which would agree with Olaniyan and Okemakinde (2008)'s assertions. This gap also calls for a comprehensive concept or model to bridge the gap.

Similarly, the equity theory was also criticized. For example, Pritchard (1969) posted that while equity theory is a significant step forward, the theory needed further specification. Pritchard (1969) argued that research supported equity predictions in the area of under payment, but the overpayment effects had not been satisfactorily demonstrated. For instance, in the present study, academics who received more skills from informal learning than they are actually needed to utilize at the time, would be synonymous with overpayment. Thus, Pritchard (1969)'s criticism of equity theory explained the insignificant findings posted from informal learning. Nevertheless, it also explained the insignificant results of horizontal promotion since receiving such promotions meant that you had the skills but you are denied the upward promotion. This gap further raised the need for a new model, which could explain these issues in totality. Hence, with the gaps discussed above, the present study came up with Professional Integration Interaction Practices (PIIP) Model, which explains the interaction and integration of professional development practices together with promotions and organizational commitment.

\section{Methodology}

The study used a descriptive, cross-sectional survey design with both quantitative and qualitative approaches. The study had a sample of 320 arrived at using simple random and purposive sampling techniques from the accessible population of 1,916 as Krejcie and Morgan (1970) table stipulates. The sample size for qualitative data was 6 as the saturation point was between 3 - 6 interviews (Morse, 1994). The respondents included senior academic staffs and administrators of both Makerere and Kyambogo Universities. Data was collected using questionnaires and interview guides. Numerical data was analyzed using Pearson Product Moment Correlation coefficient and regression analysis, while qualitative data was thematically analyzed. Further analysis was done using structural equation modeling which aided in identifying areas to be addressed by the proposed PIIP model. The new model was tested by asking respondents to rate themselves on the five-point Likert scale on the items representing; professional individuation, support, integrity and support respectively, which reflected the elements in the PIIP model.

\section{THE PROFESSIONAL INTEGRATION INTERACTION PRACTICES (PIIP) MODEL}

The gaps that were identified from the available literature and the findings of the current study necessitated the innovation of a new model as described below. The PIIP 
model is illustrated by assumed interactions between professional development practices, organizational commitment, staff promotions and professional development programs.

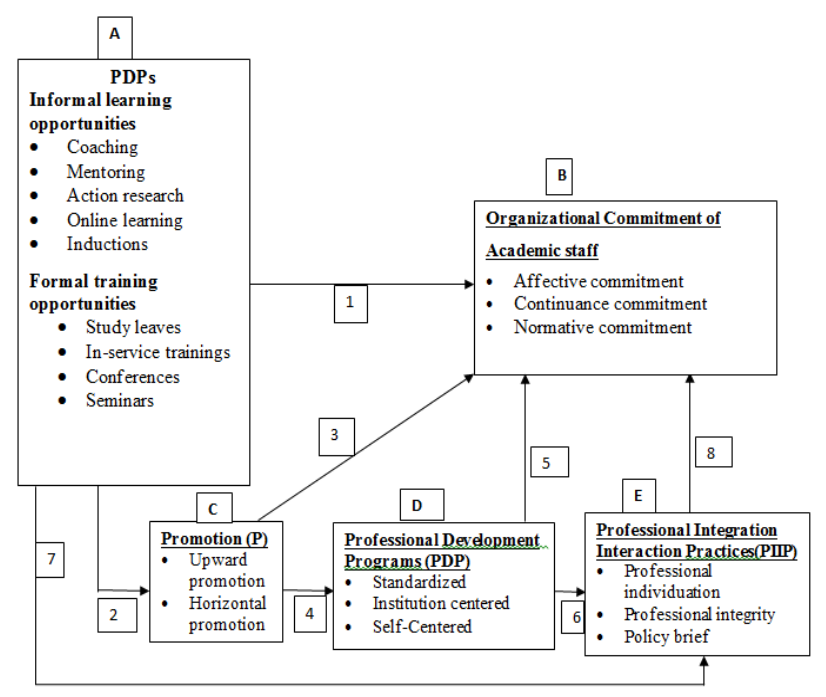

Fig. 3. The professional integration interaction practices (PIIP model).

\section{A. Assumptions of the PIIP model}

The PIIP model has got eight assumptions described by the paths in Fig. 3.

\section{A leads to B (Arrow one)}

The model assumes that professional development practices (PDPs) in universities manifest in forms of informal learning such as, coaching, mentoring, induction, action research and online learning; and formal training such as, study leaves, in- service training, conferences and seminars (Demo et al., 2012; Wan et al., 2002; Bulut \& Culha, 20210). These PDPs are assumed to have a direct influence on organizational commitment, which manifests as affective commitment, normative commitment and continuance commitment in a university setting (Allen \& Meyer, 1990). When academic staffs are given formal training, their commitment to the university improves in the same measure. This assertion was supported by study findings, which were statistically significant and positive along this path.

\section{A leads to $C$ (Arrow 2)}

Professional development practices are assumed to have a direct influence on staff promotions (upward and horizontal promotions) (Negash et al., 2014). The upward promotions are usually characterized with rising in rank, more responsibilities and increased financial benefits. On the other hand, horizontal promotions come at the same rank but with increased responsibilities and no guaranteed financial benefit. It is premised by the PIIP model that when academic staff are given skills through informal learning and formal training, they qualify for either upward or horizontal promotions. This assertion was supported by statistically significant positive study findings along this path.

\section{Cleads to $B$ (Arrow three)}

The PIIP model asserts that staff promotions have a direct influence on organizational commitment of academic staff.

\section{Cleads to D (Arrow 4)}

The PIIP model further assumes that staff promotions have a direct influence on professional development programs. The professional development programs are manifested in three ways including, standardized, institution centered or self-centered. The standardized professional programs involve educational programs, which serve as a foundation for informal learning and formal training. In the present study context, a teaching staff must have a minimum of a bachelor's degree before informal learning and formal training come into play. Basing on what an individual has achieved from the standardized professional development, the institutional centered development then gets the direction to take. A decision is taken whether the academic gets support through informal learning or formal training like further studies, conferences, seminars, or whether one needs moral or financial support or logistical support. However, the individual academic staff influences the above two professional development programs involved. For instance, the success of the mentoring or coaching program will depend on the attitude of the individual being coached or mentored. Similarly, the success of formal training depends much on the aggressiveness and innovativeness of the trainee. Hence, the self-centered approach to professional development. Therefore, the PIIP model asserts that promotions influence the nature of integration and interaction between the three professional development programs.

\section{D leads to B (Arrow five)}

This means that professional development programs have a direct influence on organizational commitment. The outcome of the integration and interaction of professional development programs is presupposed to influence organizational commit. For example, the self-centered professional development with interaction with the other two programs impacts even the individual who has received skills from informal learning to be highly committed to the organization. Hence, the support of the study findings that informal learning has an indirect statistically significant positive influence on organizational commitment through promotions.

\section{D leads to E (Arrow six)}

The PIIP model also assumes that professional development programs have a direct influence on Professional Integration Interaction Practices (PIIP). The proposition of the current study is that PIIP in the organization manifests in four ways, including; Professional individuation, Professional integrity, Professional support and Policy brief. Professional individuation is about the aspirations, values and philosophy of the employee. These personal characteristics influence the professional integrity the employee exhibits. In addition, the success of professional support given and received by employees depends on how the individuals involved perceive professional individuation and professional integrity. Take for instance the quality of mentor-mentee relationship is one of the most effective way of building teacher organizational commitment (Hong \& Matsko, 2019). This study therefore asserts that a novice academic willing to learn a skill will make it easy for a senior staff member to pass the on the skill 
to them. On the other hand, a senior member of staff assigned as a mentor will mentor the novice academic even with minimal supervision from university authorities, if the senior member values integrity. It is therefore premised by the study that professional development programs influence the outcome of PIIP. In addition, PIIP presupposes that professional individuation, professional integrity and professional support become a reality when the institution puts in place policies that provide a conducive environment for the first three elements of PIIP to thrive.

Coldron and Smith (1999) argued that identity for a teacher is partly given and partly achieved by active location in social space where they find themselves in an array of possible relations that one person can have to others. Hence, this study presupposes that in the process of individuation, an academic will make choices on whom to relate with, as long as such a relationship leads them to their goal. In fact, Coldron and Smith (1999) reported that set practices (traditions/policies) convey possible relations within social space; that the development of a teachers' professional identity is largely dependent on the quality and availability of these varied factors. It is therefore upon this basis that this study advocates for revision of policies in order to enhance professional support, professional integrity and professional individuation.

\section{A leads to E (Arrow seven)}

It was assumed that professional development practices have a direct influence on PIIP. The study asserted that the kinds of professional development practices which the university chooses to adopt as outlined under informal learning and formal training influence the outcome of PIIP. For example, however much an academic staff may be high on professional individuation, if there or no opportunities for seminar, conferences, in-service training or study leaves, the interaction with professional integrity and professional support is accordingly impacted negatively.

\section{E leads to B (Arrow eight)}

This means that PIIP has a direct influence on organizational commitment. It was assumed that when PIIP is operationalized, organizational commitment will improve as a consequence of improved professional individuation, professional integrity and professional support. For instance, in the words of one of the senior academic staff interviewed in Makerere University,

'...here individuals are concerned about making a personal brand. The university is just an address.' (Makerere University, 28/08/2019).

Such an individual would be committed to the university irrespective of the type of promotion, as long as such an academic achieves the 'personal brand'. With this argument, even the individual employee who receives horizontal promotion is committed to the university. The HCT and equity theory do not account for this relationship.

\section{B. Operationalizing the PIIP model}

Operationalization of the PIIP model elaborates the testability and workability of the model.

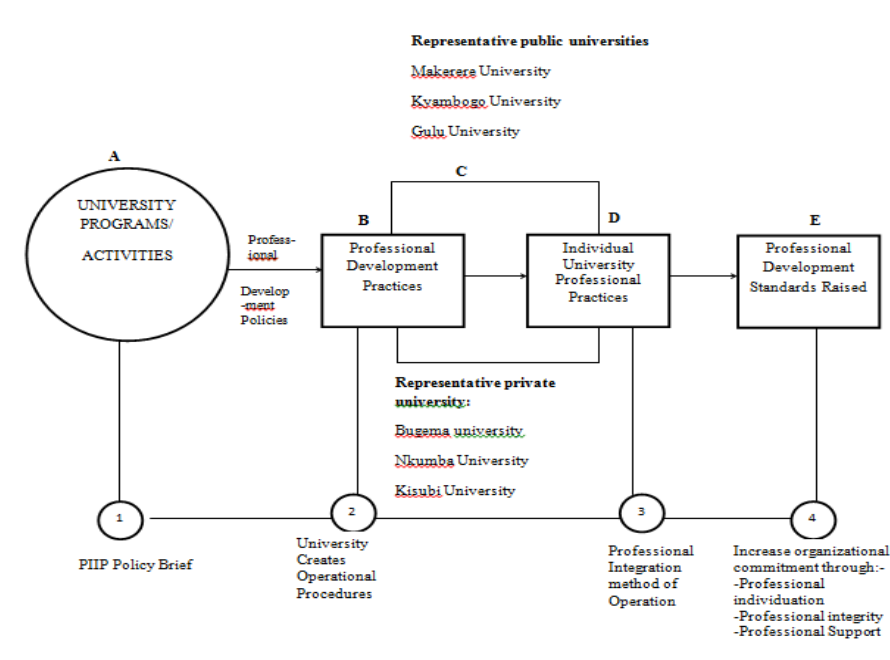

Fig. 4. Operationalizing the Professional Integration Interaction Practices (PIIP) model.

Fig. 4 shows that operationalization of PIIP is proposed to go through four stages. It also indicates that the policy brief would aim at highlighting how programs or activities in public and private universities might be influenced by PIIP.

1. When the PIIP policy brief is adopted, the existing professional development policies concerning university programs or activities would be modified to influence professional development practices in public and private universities.

2. The universities would then create operational procedures on PIIP to guide the professional development practices in public and private universities.

3. The universities involved are expected to use professional integration method of operation by use of a variety of approaches to come up with sets of professional practices unique to their respective environments. The integration is expected to be, first at the overseer level where it is expected standards would be catered for. These standards are to be set by regulators like Ministry of Education and Sports through National Council of Higher Education (NCHE). Secondly, at the institutional level, focus will be on staff promotions, informal learning and formal training practices aimed at raising professional individuation, professional integrity and professional support. Simultaneously, this level would be sensitive to self-centered programs that promote self-reliance.

4. At the final stage organizational commitment of academic staff will be increased as a consequence of raised professional development standards through improved professional individuation, professional integrity and professional support. It is presumed that when the academic staffs go through self-centered programs they will be able to improve their self-individuation in terms of the individual output and attainment of individual goals, thereby improving their organizational commitment. Also, when academic staffs are exposed to regulated professional development programs and their professional integrity is raised, their organizational commitment will improve in the sense that they will be able to work with minimum supervision, faithfully executing their professional obligations. In addition, with professional individuation and professional integrity the academic staff will be able to offer professional support to colleagues in terms of 
mentoring, coaching induction and assignment of special duties. In turn, the individuals who receive professional support will also have more organizational commitment. Institutional centered programs will also take care of the professional support needed from the university to the faculty members.

\section{Testability of the PIIP model}

Respondents were requested to rate themselves on the fivepoint Likert scale on the items A, B, C and D, representing; professional individuation, support, integrity and support respectively, reflecting the elements in the PIIP model.

TABLE IV: QUESTIONNAIRE FOR TESTING THE PIIP MODEL

\begin{tabular}{|c|c|c|c|c|c|c|}
\hline & & 1 & 2 & 3 & 4 & 5 \\
\hline A & $\begin{array}{l}\text { Realistic and relevant content } \\
\text { motivates me to participate in } \\
\text { professional development programs }\end{array}$ & & & & & \\
\hline B & $\begin{array}{c}\text { The success of professional } \\
\text { development programs depends on } \\
\text { sufficient resources to implement the } \\
\text { learning }\end{array}$ & & & & & \\
\hline $\mathrm{C}$ & $\begin{array}{l}\text { It matters to me to fulfill my } \\
\text { professional development obligations } \\
\text { irrespective of the consequences }\end{array}$ & & & & & \\
\hline D & $\begin{array}{l}\text { If policy makers addressed the issues } \\
\text { above, levels of organizational } \\
\text { commitment would improve }\end{array}$ & & & & & \\
\hline
\end{tabular}

A soft copy of the questionnaire was sent to forty-three participants on e-mail and WhatsApp, including the experimental group (academic staff in private universities represented by Nkumba, Bugema and Kisubi Brothers Universities) and control group (academic staff in public universities represented by Gulu, Makerere and Kyambogo Universities). A follow-up call was made to each participant. Thirty-one (31) responses were received, representing $72 \%$ and 19 responses from private universities while 12 respondents from public universities and experts.

TABLE V: DESCRIPTIVE STATISTICS ON PIIP FOR THE CONTROLLED GROUP (PUBLIC UNIVERSITIES)

\begin{tabular}{|c|c|c|c|c|c|c|c|}
\hline \multirow{5}{*}{ Item } & \multicolumn{7}{|c|}{ Response category } \\
\hline & \multicolumn{7}{|l|}{ SD } \\
\hline & $\mathrm{A}$ & DA & NS & A & SA & Mea & Stand \\
\hline & $\mathrm{F}$ & $\mathrm{F}(\%)$ & $\mathrm{F}(\%)$ & $\mathrm{F}(\%)$ & $\mathrm{F}(\%)$ & $\mathrm{n}$ & Dev. \\
\hline & $(\%)$ & & & & & & \\
\hline \multirow{3}{*}{$\begin{array}{l}\text { Professional } \\
\text { Individuation }\end{array}$} & 0 & \multirow{3}{*}{$\begin{array}{c}0 \\
(0.0)\end{array}$} & \multirow{3}{*}{$\begin{array}{c}0 \\
(0.0)\end{array}$} & 4 & 8 & \multirow{3}{*}{4.67} & \multirow{3}{*}{0.49} \\
\hline & $(0.0$ & & & $(33.3$ & $(66.7$ & & \\
\hline & ) & & & ) & ) & & \\
\hline \multirow{3}{*}{$\begin{array}{c}\text { Professional } \\
\text { Support }\end{array}$} & 0 & 2 & \multirow{3}{*}{$\begin{array}{c}0 \\
(0.0)\end{array}$} & 8 & 2 & \multirow{3}{*}{3.83} & \multirow{3}{*}{0.94} \\
\hline & $(0.0$ & $(16.7$ & & $(66.7$ & $(16.7$ & & \\
\hline & ) & ) & & ) & ) & & \\
\hline \multirow{3}{*}{$\begin{array}{c}\text { Professional } \\
\text { Integrity }\end{array}$} & 0 & \multirow{3}{*}{$\begin{array}{c}0 \\
(0.0)\end{array}$} & 2 & 8 & 2 & \multirow{3}{*}{4.00} & \multirow{3}{*}{0.600} \\
\hline & $(0.0$ & & (16.7 & $(66.7$ & $(16.7$ & & \\
\hline & ) & & ) & ) & ) & & \\
\hline \multirow{3}{*}{ Policy brief } & 0 & \multirow{3}{*}{$\begin{array}{c}0 \\
(0.0)\end{array}$} & 4 & 4 & 4 & \multirow{3}{*}{4.00} & \multirow{3}{*}{0.85} \\
\hline & $(0.0$ & & $(33.3$ & $(33.3$ & $(33.3$ & & \\
\hline & ) & & ) & ) & ) & & \\
\hline \multirow{3}{*}{ Grand Total } & 0 & \multirow{3}{*}{$\begin{array}{c}2 \\
(4.2)\end{array}$} & 6 & 24 & 16 & \multirow{3}{*}{4.13} & \multirow{3}{*}{0.72} \\
\hline & $(0.0$ & & $(12.5$ & $(50.0$ & (33.3 & & \\
\hline & ) & & ) & ) & ) & & \\
\hline
\end{tabular}

Legend: 4.20-5.00 Very High, 3.40-4.19 High, 2.60-3.39 Average, 1.80-2.59 Low, 1.00-1.79 Very Low
Table $\mathrm{V}$ shows that professional individuation had a very high mean of 4.67, the highest of the four constructs, and the smallest standard deviation of 0.49 . This meant that academic staff in public universities rated themselves highly on professional individuation. This implies that public universities should not take professional individuation for granted as it is the most critical factor from the perspective of the academic staff. On the other hand, professional support posted a high mean of 3.83 though it was the lowest among the means in PIIP. This implies that public universities need to encourage and offer support that is more professional to the faculty members if this component is to lead to increased organizational commitment. The table also indicates that 83.3 $\%$ of all the responses either agreed or strongly agreed with the statements, which means that the statements were relevant to the subject being investigated. Table 4 further indicated that the aggregated mean was high 4.13 with a standard deviation of 0.72 . This meant that the PIIP model is applicable in public universities. The model was also tested in private universities as results indicate in Table VI.

TABLE VI: DESCRIPTIVE STATISTICS ON PIIP FOR UNCONTROLLED GROUP (PRIVATE UNIVERSITIES)

\begin{tabular}{cccccccc}
\hline \hline & \multicolumn{7}{c}{ Response category } \\
\cline { 2 - 7 } Item & SDA & DA & NS & A & SA & Mean & $\begin{array}{c}\text { Stan } \\
\text { d. } \\
\text { Dev. }\end{array}$ \\
\hline Professional & 0 & 0 & 2 & 3 & 14 & 4.63 & 0.68 \\
Individuation & $(0.0)$ & $(0.0)$ & $(10.5)$ & $(15.8)$ & $(73.7)$ & & \\
Professional & 0 & 0 & 2 & 6 & 11 & 4.47 & 0.70 \\
Support & $(0.0)$ & $(0.0)$ & $(10.5)$ & $(31.6)$ & $(57.9)$ & & \\
Professional & 0 & 0 & 5 & 8 & 6 & 4.00 & 0.60 \\
Integrity & $(0.0)$ & $(0.0)$ & $(26.3)$ & $(42.1)$ & $(31.6)$ & & \\
Policy & 0 & 0 & 2 & 9 & 8 & 4.32 & 0.67 \\
formulation & $(0.0)$ & $(0.0)$ & $(10.5)$ & $(47.4)$ & $(42.1)$ & & \\
\hline Grand Total & 0 & 0 & 11 & 26 & 39 & \multirow{2}{*}{4.36} & 0.66 \\
\hline \hline
\end{tabular}

Legend: 4.20-5.00 Very High, 3.40-4.19 High, 2.60-3.39 Average, 1.80-2.59 Low, 1.00-1.79 Very Low

Table VI indicated that professional individuation, like in the case of the controlled group, posted the highest mean of 4.63 , which was in the range of very high with a small standard deviation of 0.68 . This meant that the academics in private universities rated themselves highly on professional individuation and they agreed to the questions in their responses. This implies that private universities need to lay more emphasis on this aspect as it is bound to lead to greater

impact on organizational commitment. Professional integrity posted a high mean of 4.0, though it was the lowest of all the means in PIIP. The private universities therefore need more integration of the professional development programs to improve professional integrity. Overall, $85.5 \%$ of all responses were either agree or strongly agree, meaning that the participants found the items relevant to the subject. The aggregated mean was very high at 4.36 , with a small standard deviation of 0.66 . This meant that the PIIP model is applicable in the private universities.

\section{Workability of the PIIP model}

From Table VI private universities posted the highest aggregate mean of 4.36 with professional individuation posting a very high mean of 4.63 . On the other hand, public universities posted a high aggregate mean of 4.13 and a very 
high mean of 4.67 posted by professional individuation. These findings reveal that the PIIP model is workable in both public and private universities with the greatest strength in professional individuation. When the Independent-samples ttest was run, it indicated that there was no significant difference in scores for private university $(M=4.39$, $S D=0.319)$ and public universities $[M=4.17, S D=0.559 ; t(31)$ $=1.394, p=0.174>0.05$, Sig $=0.062>0.005]$. This meant that the PIIP model is applicable in both private and public universities.

\section{CONCLUSION}

Since Structural Equation Modeling showed that informal learning and horizontal promotion had weak loadings on organizational commitment, Government through Ministry of Education and Sports in conjunction with National Council of Higher Education should implement the PIIP model to raise professional development standards of the academic staff and their organizational commitment. Once government appreciates the PIIP model and through National Council of Higher Education adopts it, there will be basis for policy briefs and supervision of staff promotions and professional development.

\section{ACKNOWLEDGMENT}

S. M. Muyiggwa thanks the statistician James Wanzima who worked tirelessly with him to bring out the structural equation modeling results.

\section{CONFLICT OF INTEREST}

Authors declare that they do not have any conflict of interest.

\section{REFERENCES}

Abedi, F. E., Jalvand, M. R., Sharif, M., Salimu, G. A. \& Khanzadeh, (2011). A study of influential factors on employee motivation for participation in in-service training courses based on modified expectancy theory. International Business and Management, 2(1), 157 - 159. doi: http://dx.doi.org/10.3968/j.ibm.1923842820110201.011S.A.

Adere, N. (2019). Effects of international marketing on organizational commitment of employees: The case of Awash Bank [Unpublished Master dissertation]. University of Adis-Ababa.

Allen, N. J. \& Meyer, J. P (1990). The measurements and antecedents of affective, continuance and normative commitment to the organization. Journal of Occupational Psychology, 63(1), 1-18. https://doi.org/10.11111/j.2044-8325.1990.tb00506.x

Allen, T., Eby, L., Poteet, M., Lentz, E. \& Lima, L. (2004). Career benefits associated with mentoring for protégés: A meta-analysis. The Journal of Applied Psychology, 89, 27-36; doi: 10.1037/0021-9010.89.1.127

Bampoh-Addo, H. \& Abedi-Boafo, E. (2014). A critical look at issues of conflict in academic staff promotion in Ghanaian public universities. Journal of Economics, 5(31). ISSN 2222 -288X (online).

Baruku, W. S. (1983). Secondary School Teacher Attrition in Tororo District. [Unpublished MED dissertation]. Makerere University.

Bulut, C. \& Culha, O. (2010). The effects of organizational training on organizational commitment. International Journal of Training and Development, 14(4), 309 - 322; https://doi.org/10.1111/j.14682419.2010.00360.x

Castro-Casal, C., Vila -Vazquez, G., \& Pardo- Gaypso, A. (2019). Sustaining affective commitment and extra role service among hospitality employees: Interactive effect of empowerment and service training. Sustainability,

11(15), $\quad 4092$.
Coldron, J. \& Smith, R. (1999). Active location in teachers' construction of their professional identities. Journal of Curriculum Studies, 31(6), 711 -726. http://dx.doi.org/10.1080/002202799182954

Demo, G., Neiva, E. R., Nunes, I., \& Rozzett, K. (2012). Human resources management policies and practices scale (HRMPPS): Exploratory and confirmatory factor analysis. BAR-Brazilian Administration Review, 9(4), 395-420. https://doi.org/10.1590/S180776922012005000006.

Fako, T. T., Nkhukhu-Orlando, E., Wilson, D. R., Forcheh, N. \& Linn, J. G. (2018). Factors associated with organizational commitment of academic employees in Botswana. International Journal of Educational Administration and Policy Studies, 10(6), 56 -64, https://doi.org/10.5897/IJEAPS2017.0563

Hanaysha, J. (2016). Examining the effects of employee empowerment, teamwork and employee training on organizational commitment. Procedia-Social and Behavioural Sciences, 229(2016), 298 -306. http:/creativecommons.org/licenses/by-nc-nd/4.0/

Hathorn, C. \& Dillon, A. M. (2018). Action Research and professional development: Its role in education reform in the United Arab Emirates. Issues in Education Research, 28(1), 91-119.

Hong, Y. \& Matsko, K. K. (2019). Looking inside and outside of mentoring: Effects on new teachers' organizational commitment. American Educational Research Journal, 56(6), 2368-2407. https://doi.org/10.3102/0002831219843657

Khandaker, S. A. \& Pangil, F. (2017). An empirical study for assessing the relationship between affective commitment and informal workplace learning. International Journal of Academic Research in Business and Social Sciences, 7(2). Doi: 10.6007/IJARBSS/v7-i12/3731

Krejcie, R. V., \& Morgan, D. W. (1970). Determining sample size for research activities. Educational and Psychological Measurement, 30(3), 607 - 610 https://doi.org/10.1177/00136447003000308

Lambert, E. G., Out, S. E. \& Elechu, O. (2019). Effects of workplace variables on organizational commitment of Nigerian correctional staff. International Journal of Comparative and Applied Criminal Justice. https://doi.org/10.1080/01924036.2019.1684330

Mansoor, I. B. \& Naji, A. L. A. (2017). The relationship between training and satisfaction and readiness to transfer leaning: The mediating role of normative commitment. Sustainability, 9(834). Doi: 10.3390/su9050834

Mathias, R. L. and Jackson, J. H. (2008). Human Resource Management. Thomson South-Western.

Morse, J. M. (1994). Designing funded qualitative research. In N. Denzin \& Y. Lincoln (Eds.), Handbook of qualitative research (pp.220 - 2350. Thousand Oaks, CA: Sage Publications.

Mugizi, W., Bakkabulindi, F. E. K., \& Bisaso, R. (2015). Antecedents of commitment of academic staff in universities in Uganda: A conceptual paper. Nkumba Business Journal, 14, $214-241$. https://www.researchgate.net/publication/319501981

Nachbagaver, A. G. M. \& Ried1, G. (2002). Effects of concepts of career plateaus on performance, work satisfaction and commitment. International Journal of Management. 23(8), 716 - 733. doi: 10.11.08/01437720210453920.

Negash, R., Zewude, S., \& Megarsa, R. (2014). The effect of compensation on employees motivation: In Jimma University academic staff. Basic Research. Journalof Business Management and Accounts, 3(2), 17 -27, http//www.basicresearchjournals.org

Nelssen, J., Fourrier, A. \& Verbruggen, M. (2017). Employee development and voluntary turnover: Testing the employability paradox. Human Resource Management Journal. 27(1), $152 \quad-\quad 168$. Htttps://d oi.org/101111/117.48-8583.12136

Nge'the, J. M., Iravo, M. E. \& Namusonge, G. S. (2012). Determinants of academic staff retention in public universities in Kenya: Empirical review. International Journal of Humanities and Social Sciences. 2(13), $205-212$.

Olaniyan, D. A. \& Okemakinde, T. (2008). Human capital theory: Implications for education development. Pakistan Journal of Social Sciences. 5(5), 479-483. ISSN:1683-883

Olurotimi, O. J., Asad, K. W., \& Abdulrauf, A. (2015). Motivational factors and teachers' commitment in public secondary schools in Mbale Municipality. Journal of Educational Practice, 6(15) 117 -122. http://iiste.org/Journals/index.php/JEP

Oyat, C. \& Aleni, F. G. (2015). Work environment and labour turnover in public universities in Uganda. The case of Gulu University. Prime Journal of Business Administration and Management, 3(6), 1070-1075. www.primejournal.org/BAM

Peace, H. (1992). Organizational Commitment of Female Lecturers in higher institutions of learning in Uganda: Its nature and determinant factors 1975-1993.

Plater W. M. (1995). Future Work: Faculty Time in the 21st Century. Change, 27(3), 22-33. 
Postholm, M. B. (2012). Teachers' professional development: A theoretical review. Educational Research, 54(4), $405 \quad-429$. https://doi.org/10.1080/00131881.2012.734725

Pritchard, R. D. (1969). Equity theory: A review of critique. Organizational Behavior and Human Performance. 4(20), $176 \quad-211$. https://doi.org/10.1016/0030-5073(69)9005-1

Rawashdeh, A. M \& Tsmimi, S. A. (2019). The impact of employee perceptions of training on organizational commitment and turnover intentions: An empirical study of nurses in Jord an hospitals. European Journal of Training and Development. 44(2/3), $191-207$. https:doi.org/10.1108/EJTD-07-2019-0112

Richards, J. C., \& Farrell, T. S. C. (2005). Professional development for language teachers. Cambridge: Cambridge University Press.

Robboy, S. J. \& McLendon, R. (2017). Structured annual faculty review program accelerates professional development and promotion: Long term experience of the Duke University medical center's pathology department. Academic Pathology, 4, 1 - 19 . doi: $10.1177 / 2374289516689471$

Sanders, A. \& De Grip, A. (2004). Training, task flexibility and the employability of low skilled workers. International Journal of Manpower. 25(1), 73-89. doi: 10.108/01437720410525009.

Sekitoleko, V. (1988). Lecturers Desert Makerere for Mbale. The Star. 5(631) (January 9th).

Selemogwe, M., TLhabano, K. \& Bologun, S. K. (2013). Mentoring, individual innovativeness and perceived organizational policies as predictors of organizational commitment among non-academic staff of Ibadan University. Journal Archives Des Sciences, 66(1). ISSN:661=464X

Sitienei, M., Egessa, R. \& Owano, A. (2015). The impact of training and development on employee commitment: A case of depart of children's services, Kenya. Elixir Organizational Behavior, 89(2015), 37268 37272;

Ssali K. F., Onen, D \& Musoke, G. G. (2019). Factors determining the retention of academic staff in universities. Journal of Education and Practice, 10(8), 41 -50; doi: 10.7176/JEP

Ssentongo, J. S. (2020). 'Which journal is that?' Politics of academic promotion in Uganda and the predicament of African publication outlets. Critical African Studies, 12(3), 283-301.

Steven, J. K. (2016). Human capital and rates of return: Brilliant ideas or ideological dead ends. Comparative Education Review, 60(4), 644 672. https://doi.org/10.1086/688063

Tan, E. (2014). Human capital theory: A holistic criticism. Review of Educational Research, 84(3), $411 \quad-\quad 445$. https://doi.org/10.310/0034654314532696

Thabo, T. F., Nkhukhu - Orlando, E., Wilson, D. R., Forcheh, N. \& Linn, J. G. (2018). Factors associated with organizational commitment of academic employees in Botswano. International Journal of Education Administration and Policy studies, 10(6), 56 -64. Doi: 10.5897IJEAPS2017.0563

The Inspectorate of Government (2015). Report on investigations into mismanagement and corruption at Kyambogo University, August 2015. Vol. 5 . Government of Uganda.

Timsal, A., Awais, M. \& Shoaib, O. (2016). On-job training and its effectiveness: An employee perspective. South Asian Journal of
Banking and Social Sciences,

https://www.researchgate.net/publication/305699923

Uganda Bureau of Statistics (UBOS), (2018). Manpower Survey Uganda 2016/2017. Report - Kampala, Uganda.

UNESCO. (1998). Higher Education Staff Development: A Continuing Mission. ED.99/HEP/WCHE/Vol. IV-4. Paris: UNESCO.

Unzicker, D., Clow, K. E., \& Babakus, E. (2000). The role of organizational communications on employee perceptions of a firm. Journal of Professional Services Marketing, 21(2), 87-103.

Wan, D., Ong, C. H., \& Kok, V. (2002). Strategic human resource management and organizational performance in Singapore. Compensation \& Benefits Review, 34(4), 33-42. https://doi.org/10.1177/0886368702034004006

Yangbo, S. \& Chul-Ki, C. (2019). Empirical Analysis on the impact of workplace learning on human resource performance of construction engineers. Korean Journal of Construction Engineering and Management, 20(5), 31-41. https://doi.org/10.6106/KJCEM.2019.20.5.031

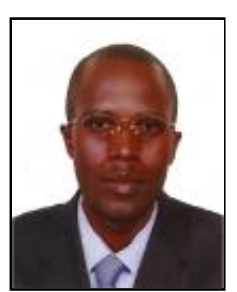

Saul M. Muyiggwa was born in Masuliita, Uganda. He holds a Doctor of Philosophy degree in Human Resource Management from Nkumba University, Entebbe, Uganda earned in 2021. Saul also holds a Masters Science degree in Human Resource Management in Education from Makerere University, Kampala, Uganda earned in 2007. Saul pursued a Post Graduate Diploma in Education majoring in Physics and Mathematics, from Makerere University, Kampala, Uganda earned in 1999. Saul holds a Bachelor of Science degree majoring in Physics and Mathematics, from Makerere University, Kampala, Uganda earned in 1997. Saul pursued Uganda Advanced Certificate of Education majoring Physics, Mathematics and Chemistry from King's College Budo, Uganda earning the certificate in1993. He got the Uganda Certificate of Education from King's College Budo, Uganda in 1990.

$\mathrm{He}$ is a part-time lecture in in Bugema University Uganda. He is also a Human Resource Consultant and Director in Pasani Consult Ltd. He has previously worked as deputy headteacher and headteacher in both private and government secondary schools. Previous publications include, S. M. Muyiggwa, J. P. Kasujja and S. P. Ongodia (2020). Professional development practices and organizational commitment of academic staff in Ugandan public universities: A case of Makerere and Kyambogo Universities. International Journal of Education and Research. 8(7). 255 278.

Dr. Muyiggwa is a Peer Reviewer for Asian Basic and Applied Research Journal, and Journal of Scientific Research and Reports. He is currently working on exploratory research on domestic workers in Africa, and has been awarded certificates of excellent work in peer reviewing. Dr. Muyiggwa is a Board member for Ishaka Adventist Hospital and the Chairman Board - Adventist Medical Center. 